\title{
The Meaning of Religious Dialogue: According to Christian-Muslim Theologians in Pakistan
}

\author{
Muhammad Shahid Habib
}

\begin{abstract}
The study is the presentation of different forms of dialogues in Pakistan. Dr. De Souza has analyzed briefly how in an Islamic state, Christians are enjoying equal rights with a spirit of social service and sharing. Jan Slomp's viewpoint is that dialogue is difficult to take place in Pakistan because of Muslims' arrogance, as they are a majority and Christians are also not prepared for dialogue because of their Hindu background. According to John O'Brien, secular system in Pakistan would favor all the communities. If Islamic system is implemented, it would have negative effects on promoting dialogue. Dr. Ansari proposes that Muslims could spell out and, together with Jews and Christians, strive for such values that would please God. Dr. Khalid Alavi says about the inter-religious dialogue, "it is the new tactic which is used to confuse the Muslims in inter-religious dialogue. In diplomatic language, it is called "engagement". According to Khalid Jameel, the dialogue should be based on equality. The dialogue is useless if we do not reach up to their level of growth, advancement and development.
\end{abstract}

Keywords: Pakistan, Dialogue, Christian, Muslim and Religion

\section{Introduction}

It is a fact that Pakistani Muslims hardly played a role in dialogue whenever and wherever it was organized. There are some misunderstandings regarding dialogue in Pakistan. There is a huge gap between the followers of Islam and others. No proper interaction is found among the people. The followers of every religion have their own ideologies, which obstruct them from mixing with others. Many critics have viewed the situation from different angles. They have highlighted some problems, which create difficulties in carrying out dialogue in Pakistan.

\section{Christian Theologians and Dialogue in Pakistan a. Jan Slomp and Dialogue}

Jan Slomp in an article "problems and possibilities for dialogue in Pakistan" has narrated a brief history of dialogue. He has discussed at length why dialogue does not thrive in Pakistan. To him, there are certain reasons for that.

First of all, the Christian community was not ready for that as it carries with it the Hindu background. Secondly, Muslims had never accepted non-Muslims in Pakistan as equal partners. There had always been difference in that. Another reason may be that the Christian Church had no people for dialogue at an academic level. The well-trained ones unusually migrate to Europe or are too busy with their own work to go for extra activities. The arrogance of majority and ghetto mentality of minority is also a hurdle in dialogue.

Beside these problems, Jan Slomp ${ }^{1}$ has pointed out some other reasons for the failure of dialogue in Pakistan. To him there are deeper religious and political reasons embedded in the Islamic culture. To Muslims, the final book, The Holy Quran has settled all the issues. To revise them would mean that Muslims have doubts in the final revelation. In other words, dialogue is dangerous for their faith. The Pakistani scene provides a gloomy picture of conflict among the Muslims themselves. There have been made some fruitless efforts in this regard. Beside this, in Pakistan, people view the Christian mission as enemy of Islam. ${ }^{2}$

To conclude Jan Slomp's viewpoint, it can be stated that dialogue was difficult to take place because of Muslims' arrogance, as they are a majority. The Christian Church had no academic personalities for dialogue. Christians are also not prepared for dialogue because of their Hindu background. Dialogue is also difficult because of deeper religious and political reasons. All these problems can be overcome only when misunderstandings are removed and there is religious liberty for every sect.

\section{b. John O'Brien and Dialogue}

John O'Brien ${ }^{3}$ has also discussed dialogue in different forms in Pakistan. Regarding this, he says that Muslims and Christians go for shared struggle for many achievements. They come closer to each other at work places, educational institutes, hospitals, etc. They are also seen together for prayers. Besides, in the matters of daily life, they meet to facilitate each other. All this has led the Muslims and Christians to religious harmony. They have developed respect for each other. John 
O'Brien while discussing dialogue has on the contrary also highlighted some areas that could not be accepted by Christians. These are the issues that have created difference between Muslims and Christians. In an Islamic state, Christians are bound to study some part of the Holy Quran at school. The punishment for blasphemous remarks about the Holy Prophet of Islam $(S A W)$ is death. This has negatively affected interreligious dialogue. Similarly, non-Muslims could be witnesses of any incident in the court of law. But they could not be equal to the Muslims. In short, the government of Pakistan has tried to implement Islamic law in the country. If it is so, then people of other religions are bound to follow Islamic system of life. John O'Brien has pointed out this important aspect that has silenced Christians and made them suffer in certain respects. To him, there should be a secular system in Pakistan that would favor all the communities. If Islamic system is implemented, it would have negative effects on promoting dialogue. Christians in that case would have to become quite passive and remain silent. They cannot have freedom to express themselves. ${ }^{4}$

\section{c. Dr. De Souza and Dialogue}

Discussing the condition of dialogue in Pakistan Dr. De Souza, ${ }^{5}$ says that Christians and Muslims have been living together in Pakistan since 1947. There is a dialogue of life between them in many fields. They are neighbors, co-workers, classmates, colleagues, etc. and have mutual respect and harmony. This dialogue has been at the common level and had no deeper roots. It can be seen as a form of co-existence. Secondly, with the passage of time, both Muslims and Christians have been getting closer to each other on humanitarian basis. The social, political and economic activities are carried out together for the welfare of the people and the state. This has been going on throughout the whole of Pakistan. Thirdly, finally, the proper form of dialogue is that when the scholars of the two religions meet and discuss religious matters. This dialogue is limited to selective people. There has been a growing interest in various parts of the country in this form of dialogue. ${ }^{6}$

The above-mentioned forms of dialogues really are found in Pakistan. Dr. De Souza has analyzed briefly how in an Islamic state, Christians are enjoying equal rights. In the social setup of the country, life runs with no difference among the people regarding religion. A spirit of service and sharing is found in the society. There are certain organizations also which are working for the betterment of relations of different religions. Scholars of Islam and Christianity meet to share their views about different issues.
In the editorial of "Focus," the situation of dialogue is discussed in detail. In the same writing, the difficulties and results of conducting dialogue in Pakistan have been highlighted.

Both Muslims and Christians face difficulties. The Muslims think that there may be a hidden agenda behind dialogue. The most notable notion is that this is a mean to convert others. The government's determination to implement Islamic Laws worries the Christians. Thus, they hesitate for dialogue and consider themselves as second-class citizen. Most of the Christians struggle to survive and cannot spare time for dialogue. They often blame Muslims for their problems.

It means that dialogue has been obstructed because of misunderstanding about its very nature. Both Muslims and Christians are afraid of being converted. Christians are worried about their survival so they cannot go for dialogue. ${ }^{7}$ These are the views from Christian scholars. As far as Muslims are concerned, they resist dialogue as a part of Christian Mission. To them, dialogue is a platform where the Christians try to explain their own problems and superiority, hence trying to convert the people. Some of the examples to clarify this view can be stated as under:

In the first Pakistan Conference for Christian Education that was held in Multan it was said, "Christian minorities could not survive without meaningful inter-religious dialogue in Pakistan. So it should be the duty of Christian teachings that the Christian children and adults should be prepared for the interreligious dialogue".

A conference titled, "Asian Journey 1997" was held in Pakistan by Pastoral Institute, Multan continued from January 20-30, 1997. The participants were from ten countries of Asia, Europe and Australia. The participants of the conference were given the chance to visit Pakistan, see the people and know the present situation themselves for two days. After that, these participants gathered in Pastoral Institute, Multan, and had a sitting for a goal and had a commentary and social analysis according to their experiment and observation. ${ }^{9}$

The conference participants decided keeping in view their observations that for the Muslim-Christian relationship, Christian preachers should concentrate on their education. Especially, the Christians should be encouraged for their treatment towards Muslim neighbors, have a positive voice towards Islam and have a critical view towards distinctive governmental policies. The participants of the conference had in their mind that "there is no difference between the inter-religious dialogue and Bible". It is the two in one. ${ }^{10}$ 


\section{Muslim Theologians and Dialogue in Pakistan}

\section{a. Dr. Zafar Ishaq Ansari and Dialogue}

Dr. Ansari ${ }^{11}$ in his article "Reflections on Islamic Bases for Dialogue" proposes that Muslims could spell out and, together with Jews and Christians, strive for such values that would please God.

According to Ansari, "The need for dialogue with people of other religious convictions arises from the concern of Muslims with the welfare of their fellow beings. Muslims are under the obligation to bear witness to the truth revealed to Muhammad $(S A W)$ and prompter to share it with the rest of humanity. Ansari suggests that the Muslim's attitude towards people who decline to identify themselves with Islamic doctrines ought to be one of mutual fellowship and cordiality (without compromising the Muslim duty to make the word of God prevail), if such persons refrain from active hostility to Islam and Muslims". ${ }^{12}$

Ansari's point of view is also remarkable. Dialogue with People of the Book is needed for the welfare of fellow Muslims. Muslims are obligated to share the truth with others. Through dialogue, non-Muslims can be refrained from active hostility towards Islam.

\section{b. Dr. Khalid Alavi and Dialogue}

For these reasons, some Muslim scholars think that dialogue is a secret agenda of Christians through which they are achieving their aims. As Dr. Khalid Alavi ${ }^{13}$ says about the inter-religious dialogue, "it is the new tactic which is used to confuse the Muslims in interreligious dialogue. In diplomatic language it is called "engagement". According to this, a relationship is maintained with the opposition to know their planning, their intentions and psychology and thus mould their own line of setting. According to this, the opposition has no way out". ${ }^{4}$ In the last three centuries, Christians shaped themselves in a colonialism that targeted Islam, Muslim and the Muslim world. The Church started dialogue to engage the Muslims and through this they are achieving their different aims. On the one hand, Muslim-Christian relationship is popularized in Muslim societies while on the other hand, they are clearing the way for Christianity through this, and different sects of Christians are holding a dialogue with Muslims. Further explaining the dialogue, Dr. Khalid Alavi says that the church has an advantage that it is an organized religious institute while in the Islamic world except for the Shi'a; there is no organized religious group. Saudi Arabia and Libya have maintained some organizations that are working under their government and representatives of their government but the Islamic world does not have any organized system. So the question is: to what end should one conduct a dialogue and with whom? No one knows the answer to this. ${ }^{15}$

Churches choose the Muslim members who are called in for dialogue and then a policy statement is issued. In such activities of dialogue, the churches and European States' policies are prepared and enforced. The topics of the dialogue are those which the European countries set to pressurize the Muslim societies, such as freedom of women, human rights, non-Muslim minorities, Islamic states secularization and enforcement of Shariah. In these dialogue meetings, the behavior of the Christian participant is aggressive and instructive while the Muslims behavior is defensive and apologetic. ${ }^{16}$

\section{c. Khalid Jameel and Dialogue}

Khalid Jameel, the director of the department of publications of Karachi University said "we should not have dialogue with these Christians because the western powers are supporting them, and they are well organized in their political, economic and defensive systems.

The dialogue should be based on equality. The dialogue is useless if we do not reach up to their level of growth, advancement and development. ${ }^{17}$

Thus, dialogue according to Muslim theologians, is to confuse the Muslims as it is a kind of engagement in order to know their planning and intentions. Church is an organized religious institute while there is no organized religious group of Muslims. Churches choose the Muslim members and just inform them of their policy statement. Through dialogue, the European countries pressurize the Muslim societies through aggressive and instructive behavior. Dialogue is part of The Christian mission in Pakistan. The churches and Christians are funded by foreign countries promoting the agenda of Christians and European secular powers. They have better political, economic and defensive systems and dialogue is possible only on the basis of equality.

\section{Conditions and Purposes for Dialogue in Pakistan}

The most important thing to keep in mind is that dialogue should never be used as a tool for conversion or as a means for evangelization. This not only prevents dialogue from happening but also causes the participants to approach each other mistrustfully. ${ }^{18}$ As Christians struggle hard to promote their mission, the Muslims too want to preach the message of Islam to all mankind. But the important point is that none of them should try to force the others to accept their respective religion. Another condition for dialogue is that the par- 
ticipants should accept each other as they are. Both Muslims and Christians should be aware of similarities and differences. ${ }^{19}$ They must be respectful to each other. During dialogue, the parties should learn more about each other. This would guide them for mutual understanding. This is the only way for dialogue.

The controversial issues cannot hold the dialogue to continue. The participants should avoid controversy as much as possible. If Christians and Muslims look for conflicts between them, there are many. Sorry to say, these do not lead them to dialogue. It means that Muslims and Christians should meet to discuss the issues helpful for the betterment of mankind and for the establishment of a peaceful society. ${ }^{20}$

There are certain common points such as God's will and dignity of human beings. Only these can only make Muslims and Christian come closer to each other. Beside these conditions, the participants of dialogue should be clear about the meaning of dialogue. It is not a debate. Dialogue is a means to learn, i.e., change and grow in perception and understanding of reality. ${ }^{21}$

According to Prof. Dr. M. M. Dheen Muhammad, ${ }^{22}$ dialogue here does not mean doubt in the faith as in dictionary, but it means non-violence scientific method in comparative religions which was not known before except after the ascendant of the Holy Quran.

Previous religions or people do not find this method in their holy books or resources. Western people in the Medieval Age, or in the age of Islam never knew as the term of dialogue in their religious faith, nor do they do they believe it. ${ }^{23} \mathrm{~S}$. W. Ariarajah also points out that:

Dialogue by nature is a two-way traffic; those who insist and behave as though they are the only ones on the road are bound to meet with accidents and the purpose of dialogue will be lost. ${ }^{24}$

These are some of the basic conditions for dialogue. If both sides follow these, then dialogue can be fruitful. Besides, Muslims and Christians should also overcome ignorance, bias and misunderstandings. Each community of faith should be encouraged to have an open mind towards other faiths. It should also get knowledge about it. Religions must be taught in the right manner. Both quantity and quality must be so that the learner can easily get true picture of that religion. For the Muslims, it is necessary to train the people in all fields of western knowledge. The Christians have highly qualified people who enter into dialogue. They have many Islamologists who are experts in matters of Islam. ${ }^{25}$ On the other hand, Muslims have not only been far away from other religions, but have no real Muslim christia- nologist. To have dialogue in its true sense, it is necessary to train the people, as communication necessarily needs to know how and what to communicate.

\section{Conclusion}

Dialogue can only be possible if the participants are open minded. They should not try to convert each other. Both Muslims and Christians should learn about each other's religion as much as possible. They should remain respectful to each other. The controversial issues must be avoided in dialogical discussions. Muslims should train their scholars in all fields of knowledge. The importance of any particular religion for its followers must be accepted. Only these conditions can lead to a fruitful dialogue. Islam is the religion that first of all started dialogue and taught the principles and conditions for it. It is obligatory for Muslims to prepare themselves according to Quranic teachings and propagate the message of Islam. It must be made clear that Islam is the only religion, which guarantees world peace, brotherhood, tolerance, human rights and religious harmony. It is undoubtedly a code of life for mankind. 


\section{References and Endnotes}

${ }^{1}$ John, Slomp (1932) had been a prominent figure among the Western Christian scholars who worked hard to promote relationship between the Muslims and Christians. He belonged to a Dutch reformed Church as a missionary. John Slomp was brought up as a missionary who would be able to serve the mission among the Muslims. He studied Islam and Arabic language and literature. After the early education, John Slomp chose Pakistan where he could propagate the Christian mission. He learnt the Urdu language and came to Pakistan in 1974 as a missionary. Here he joined a Church in Sahiwal and took great interest in the affairs and problems of local Christians. He got many chances to work with the other European ecumenical and dialogical organizations. The representative of the Christian Study Center "Al-Mushir" has published numerous articles of John Slomp. See, 'Alam-e-Islam and 'Isayyat", (January 1995), 29-30; See for more details of his life and missionary work: Muslims and Christians in Europe: Breaking new grounds, Ch: 3, (Netherland, 1993).

${ }^{2}$ Dayanadan Francis (ed.). New Approaches to Inter-Faith Dialogue (Sweden: The Church of Sweden Mission, 1972), 83-88.

${ }^{3}$ Johan, O'Brien, was born in Ireland and studied science, education and theology. He worked as a teacher in Sierra Leore, as a community activist in inner city Dublin and has lectured on theology in many countries, He first came to Pakistan as a missionary in 1977 where he continues to live and work among marginalized minorities. His books include Theology and the option for the poor (Collegeville), Seeds of a new Church (Colombia) and Naia Mashra Naia Insan (Karachi), Urdu.

${ }^{4}$ See, Johan, O’Brien, "Our presence to the world of Islam in Pakistan". In Encounter, (Documents for Muslim Christian understanding), (Italy, Roma: Pontifico Istituto Di Studi Arabi E D’Islamistica Viale Di Trastevere, 2004), 7 9.

${ }^{5}$ Achilles De Souza, a Pakistani priest of the Archdiocese of Karachi, was born in Karachi in 1942. He holds a PhD from the Gregorian University (Rome) and his doctoral thesis was entitled "Mediation in Islam: an Investigation". For more than twenty years he has been teaching philosophy, Islamic studies and Christian-Muslim relations at Christ the King Seminary in Karachi.

${ }^{6}$ De Souza, Achilles, "Dialogue in the Islamic Republic of Pakistan." In Islamo Christiana, (Italy, Rome: Pontifico Istituto Di Studi Arabi E D'Islamistica, Vol. 4, 1988), 215-217; See also The Christian Voice, (Karachi: Vol. XIVI, No.42, Sunday, October 1995).

${ }^{7}$ See, Focus, (Multan: Pastoral Institute, Vol. 2, 1988), 102103.

${ }^{8}$ Ibid. (July 1997), 7.

${ }^{9}$ See, Focus, (Multan: Pastoral Institute, vol. 3, 1988), 8082.

${ }^{10}$ See, Alam-e-Islam owr Esayait, (Islamabad: Institute of Policy Studies, 1995, (May 1997), 17.
${ }^{11}$ Dr. Zafar Ishaq Ansari (born 27 December 1932) is a scholar of Islamic Studies. He is the Director General of the Islamic Research Institute of the International Islamic University. Previously, he has also been the President of the International Islamic University Islamabad. He has published a number of books and articles, and has spoken at international conferences on Islamic Studies and interreligious dialogue. Dr. Ansari obtained his M.A. and PhD from the Institute of Islamic Studies,McGill University, Montreal, Canada in 1966. His main thesis for his PhD program was titled "The Early Development of Figh in Kufah with special reference to the works of Abu Yusuf and Shaybani".

${ }^{12}$ Von Denffer, Ahmad, Some Reflections on Dialogue between Christians and Muslims, (UK, Leicester: The Islamic Foundation, 1989), 18.

${ }^{13}$ Dr. Khalid Alavi was an Ex-Director of Dawah Academy, International Islamic University, Islamabad

${ }^{14}$ See, Dawah (monthly), (Islamabad: Dawah Academy, International Islamic University, July, 2005), 47.

${ }^{15}$ Ibid., 48.

${ }^{16}$ See, Dawah (monthly), (Islamabad: Dawah Academy, International Islamic University, July, 2005), 48.

${ }^{17}$ Taken an interview on $25^{\text {th }}$ November, 2005, Islamabad.

${ }^{18}$ Talbi, Muhammad, Islam and Dialogue (UK, Leicester: The Islamic Foundation, 1997), 88.

${ }^{19}$ See, Inter-religious Documents 1: Guidelines for Dialogue between Christians and Muslims, Prepared by Maurice Borrmans, (New York: Paulist Press, 1990), 31-32.

${ }^{20}$ W.M. Watt, Islamic Revelation in the Modern World, (Edinburgh, 1969), 121.

${ }^{21}$ See, Guidelines On Dialogue ${ }_{2}$ (Geneva: World Council of Churches, 1982), 8-9.

${ }^{22}$ Prof. Dr. M. M. Dheen, Muhammad who was the head of Department of Comparative Religion in the Faculty of Islamic Studies (Usuluddin) IIU, Islamabad.

${ }^{23}$ Dheen Muhammad, "Min Manahij-il-Ulama-e-Muslimeen fi Dirasat-i-Adyan," In Al-Howliya, Al-Jamia Al-Islamia Al-Alamia, Islamabad: International Islamic University, Vol. 3, 1995), 93-94.

${ }^{24}$ Ariarajah, S. Wesley, "The understanding and Practice of Dialogue: Its Nature, Purpose and Variations." In Faith the Midst of Faiths, S. J. Samartha, ed., (Geneva; W. C. C., 1977), 54-56.

${ }^{25}$ Talbi, Muhammad, "Possibilities and Conditions for a better understanding between Islam and the West" In Journal of Ecumenical Studies, vol. 25, No. 2, (spring 1988):184. 


\section{Selected Bibliography}

Ariarajah, S. Wesley, "The understanding and Practice of Dialogue: Its Nature, Purpose and Variations." In Faith the Midst of Faiths, S. J. Samartha, ed., Geneva; W. C. C., 1977.

Borrman Maurice. Inter-religious Documents 1: Guidelines for Dialogue between Christians and Muslims. New York: Paulist Press, 1990), 31-32.

De Souza, Achilles, "Dialogue in the Islamic Republic of Pakistan." In Islamo Christiana. Italy, Rome: Pontifico Istituto Di Studi Arabi E D'Islamistica, Vol. 4, (1988)

De Souza, Achilles, The Christian Voice. [Karachi: Vol. XIVI, No.42, (Sunday, October 1995)].

Francis Dayanadan. (ed.). New Approaches to Inter-Faith Dialogue. Sweden: The Church of Sweden Mission, 1972.

Johan, O'Brien, "Our presence to the world of Islam in Pakistan". In Encounter. [Documents for Muslim Christian understanding), (Italy, Roma: Pontifico Istituto Di Studi Arabi E D'Islamistica Viale Di Trastevere, 2004]

Muhammad, Dheen, "Min Manahij-il-Ulama-e-Muslimeen fi Dirasat-i-Adyan," In Al-Howliya, Al-Jamia Al-Islamia AlAlamia, Islamabad: International Islamic University, Vol. 3 (1995).

Slomp, John. Muslims and Christians in Europe: Breaking New Grounds. Netherland, 1993.

Talbi, Muhammad, "Possibilities and Conditions for a better understanding between Islam and the West" In Journal of Ecumenical Studies, vol. 25, No. 2, (spring 1988).

Talbi, Muhammad, Islam and Dialogue. UK, Leicester: The Islamic Foundation, 1997.

Von Denffer, Ahmad, Some Reflections on Dialogue between Christians and Muslims. UK, Leicester: The Islamic Foundation, 1989.

Watt, W. M., Islamic Revelation in the Modern World. Edinburgh, 1969. 